\title{
MODELING YIELD, SOIL WATER BALANCE, AND ECONOMIC RETURN OF SOYBEAN UNDER DIFFERENT WATER DEFICIT LEVELS
}

\author{
Mirta T. Petry ${ }^{*}$, Laudenir J. Basso ${ }^{1}$, Reimar Carlesso ${ }^{1}$, Maria S. Armoa ${ }^{2}$, Jonas R. Henkes ${ }^{3}$ \\ ${ }^{1 *}$ Corresponding author. Universidade Federal de Santa Maria - UFSM/ Santa Maria - RS, Brasil. \\ E-mail: mirta.petry@mail.com | ORCID ID: https://orcid.org/0000-0002-4933-607X
}

\author{
KEYWORDS \\ Glycine max, soil \\ water balance, \\ SIMDualKc model, \\ economic return.
}

\begin{abstract}
Evaluating the impacts of water stress on crop yield allows comparing irrigation management alternatives, aiming to ensure an economic return for the irrigated farms. Thus, the main objectives of this study were to model the soil water balance, deriving the crop coefficients, grain yield prediction, and economic return of soybean grown at different levels of water deficit and price quotations. The experiment was carried out under a rainout shelter, using four irrigation water managements. Irrigations were applied when the soil available water in the root zone reached $75 \%, 64 \%, 60 \%$, and $50 \%$ of the total available water (TAW). Crop and soil parameters were monitored throughout the crop season. The SIMDualKc model was used to simulate the soil water balance. Statistics indicators demonstrated the goodness of the simulation, with regression coefficients $\left(b_{0}\right)$ ranging from 0.96 and 0.99 and root mean square errors (RMSE) $\leq 8.4 \mathrm{~mm}$. Crop coefficients for initial, intermediate, and final stages were calibrated and validated at 0.15 , 1.00 , and 0.10 , respectively. Crop yield and economic return were higher for the treatment kept at $75 \%$ of TAW, results that should be considered in irrigation management programs.
\end{abstract}

\section{INTRODUCTION}

Soybean (Glycine max L.) is the major oilseed crop cultivated worldwide. In Brazil, the total cultivated area of soybean reached 34 million hectares, producing 114 million tons per year, with the State of Rio Grande do Sul responsible for nearly $17 \%$ of the country's production (CONAB, 2019).

Globally, irrigated agriculture uses nearly $70 \%$ of the freshwater annually withdrawn from any water resource (UNESCO, 2018). In some cases, irrigation management can be improved by adopting deliberate deficits that while affecting negatively crop evapotranspiration $\left(\mathrm{ET}_{\mathrm{c}}\right)$ and grain yield, maintain a positive economic return (Rodrigues et al., 2013). For most cultivated plants, $\mathrm{ET}_{\mathrm{c}}$ is the sum of the water that evaporates from the soil surface $\left(E_{s}\right)$, direct evaporation of water intercepted by the plant canopy $\left(\mathrm{E}_{\mathrm{i}}\right)$, and crop transpiration $\left(\mathrm{T}_{\mathrm{c}}\right)$, with $\mathrm{E}_{\mathrm{i}}$ being almost insignificant compared to $E_{s}$ and $T_{c}$. Both components are governed by the atmosphere evaporative demand which is characterized by the evapotranspiration of a reference crop $\left(\mathrm{ET}_{\mathrm{o}}\right)$ (Graham et al., 2016). Added to many other factors,
$\mathrm{T}_{\mathrm{c}}$ is affected by crop development stages and soil water content in the whole root zone, while $E_{\mathrm{s}}$ is affected by factors that alter soil surface conditions, such as soil moisture, soil type, and the presence or not of crop residues (Wei et al., 2015).

The role of $E_{s}$ and $T_{c}$ is distinct in an ecosystem: while $T_{c}$ is associated with plant productivity, $E_{S}$ does not directly contribute to production (Kool et al., 2014). Thus, partitioning these two components significantly improves water use efficiency (WUE) (Ma \& Song, 2019). Methods for direct measures of $T_{c}$ generally are based upon sap flow measurement in a specific interface along the soil-plantatmosphere continuum, while some models use degrees of variations of the flux resistance through the plants (Kool et al., 2014). Although there are numerous models to predict $\mathrm{T}_{c}$, most of these are complex and require a great number of input parameters, which are difficult to measure or estimate (Ran et al., 2017). The SIMDualKc soil water balance model, which uses the dual crop coefficient approach, that is, separates $E_{s}$ from $T_{c}$, using an evaporation coefficient $\left(\mathrm{K}_{\mathrm{e}}\right)$ and a basal crop coefficient $\left(\mathrm{K}_{\mathrm{cb}}\right)$, related to transpiration (Allen et al., 1998, 2005), is considered one of

\footnotetext{
${ }^{1}$ Universidade Federal de Santa Maria - UFSM/ Santa Maria - RS, Brasil.

${ }^{2}$ Universidade Nacional de Assunção - UMA, Faculdade de Ciências Agrarias/ San Lorenzo, Paraguay.

${ }^{3}$ Universidade Estadual de Maringá/ Maringá - PR, Brasil.
} 
the simplest models to compute $\mathrm{E}_{\mathrm{s}}$ and $\mathrm{T}_{\mathrm{c}}$ separately (Qiu et al., 2015).

The soil water balance is computed by the inflows and outflows of water from a given soil, based on the mass conservation principle, for a vegetated soil volume (Pereira \& Paredes, 2018). Its determination is extremely important for water management and savings, especially in irrigated systems, and can be done in two ways: a) by observing soil water content, using measuring equipment (TDR, FDR, tensiometer, neutron probe, etc.), which may have hourly, daily, or other time measures throughout the crop development season and b) via meteorological data, calculating the reference evapotranspiration $\left(\mathrm{ET}_{\mathrm{o}}\right)$ according to the Penman-Monteith equation as described by Allen et al. (1998), and associate it with a crop coefficient $\left(\mathrm{K}_{\mathrm{c}}\right)\left(\mathrm{ET}_{\mathrm{c}}=\right.$ $\mathrm{ET}_{\mathrm{o}} \mathrm{K}_{\mathrm{c}}$ ), for each crop stage (Pereira et al., 2015).

In agriculture, the issue of water use is always much discussed, due to the impact on crop productivity. However, it is important to consider that the ultimate goal of the agricultural producer is to obtain the best economic return on investments. Moreover, few studies refer to the economic impacts of deliberate deficits applied to crops (Paredes et al., 2018). According to Klocke et al. (2012), decision making about the use of deficit irrigation is related to yield, prices of commodities, and the production cost, used to calculate economic return. Thus, the main objectives of this work were to simulate the soil water balance to derive the basal crop coefficients $\left(\mathrm{K}_{\mathrm{cb}}\right)$, predict grain yield and economic return of soybean under different levels of applied deficits.

\section{MATERIAL AND METHODS}

\section{Description of the study area and experimental design}

The study was conducted at the experimental area of the Rural Engineering Department, Federal University of Santa Maria (UFSM), located at 29 $43^{\prime} 41^{\prime \prime S}$ and 53 $43^{\prime} 11^{\prime \prime}$ $\mathrm{W}$, and altitude of 100 meters. The soil at the experimental field was classified as Ultisol (Soil Survey Staff, 2014) or an Argissolo Vermelho Distrófico arênico (Streck et al., 2008) with a loam texture in the superficial layers and clayey below $0.70 \mathrm{~m}$. According to the Köppen-Geiger climate classification, the climate in this region is a subtropical humid, classified as "Cfa," with no defined dry season and hot summers (Kottek et al., 2006).

The experiment was carried out during the 2014/15 crop growing season, inside a rainout shelter which consists of a pair of metallic structures $(16 \times 10 \mathrm{~m})$, supported by metallic rails. This structure, which is electro-mechanic activated, was moved to cover the $320 \mathrm{~m}^{2}$ area before rainfall events, in order to prevent water entry in the experimental field other than by irrigation. A completely randomized design was used, with four irrigation managements and three replications, in experimental plots of $9 \mathrm{~m}^{2}(3 \times 3 \mathrm{~m})$. The irrigation management levels were calculated to reach $75 \%, 64 \%, 60 \%$, and $50 \%$ of the total available soil water (TAW).

Weather data were obtained from an automatic meteorological station linked to the National Institute of Meteorology (INMET), located at $300 \mathrm{~m}$ from the experimental area. The data observed in a daily scale included: rainfall $(\mathrm{mm})$, maximum and minimum relative humidity $(\%)$, wind speed at $2 \mathrm{~m}$ height $\left(\mathrm{m} \mathrm{s}^{-1}\right)$, maximum and minimum air temperature $\left({ }^{\circ} \mathrm{C}\right)$, solar radiation $\left(\mathrm{MJ} \mathrm{m}^{-2}\right.$ $\left.\mathrm{dia}^{-1}\right)$, and barometric pressure $(\mathrm{kPa})$. The reference evapotranspiration $\left(\mathrm{ET}_{\mathrm{o}}\right.$ ) was computed using the PenmanMonteith method (Allen et al., 1998).

The soybean variety glyphosate-resistant Pionner®95R51, designated as 5.5 maturity group, was manually sown in a conventional cropping system, on November 30,2014 , with a population of 28 plants per $\mathrm{m}^{-2}$ and rows $0.50 \mathrm{~m}$ apart. Fertilization was applied at planting, based on the soil chemistry analysis at the $0.0-0.10 \mathrm{~m}$ layer, determined approximately 30 days before planting, which presented: $\mathrm{pH}\left(\mathrm{H}_{2} \mathrm{O}\right)(1: 1)=5.6 ; \mathrm{P}=27.2 \mathrm{mg} \mathrm{dm}^{-3}$; $\mathrm{K}=272 \mathrm{mg} \mathrm{dm}^{-3} ; \mathrm{Ca}=7.6 \mathrm{cmol}_{\mathrm{c}} \mathrm{dm}^{-3} ; \mathrm{Mg}=3.0 \mathrm{cmol}_{\mathrm{c}} \mathrm{dm}^{-}$ ; and organic matter $(\mathrm{OM})=3.1 \%$. The amount of $200 \mathrm{~kg}$ $\mathrm{ha}^{-1}$ of 00-20-20 NPK formulation was applied according to the Soil Fertility and Chemistry Commission of the Rio Grande do Sul and Santa Catarina states (2004).

The soil physical characteristics of the experimental field are presented in Table 1 . Field capacity $\left(\theta_{\mathrm{FC}}\right)$ was assumed to be the soil water content 24-hours after soil saturation by irrigation (100 $\mathrm{mm}$ of irrigation depth). Water content was measured by frequency-domain reflectometers (FDR) that have been installed in each soil layer since 2010.

TABLE 1. Soil physical properties of the experimental field.

\begin{tabular}{|c|c|c|c|c|c|c|c|}
\hline \multirow[t]{2}{*}{ Depth (m) } & \multirow{2}{*}{$\begin{array}{c}\rho b \\
\left(\mathrm{Mg} \mathrm{m}^{-3}\right)\end{array}$} & \multicolumn{3}{|c|}{ Soil texture (\%) } & \multicolumn{2}{|c|}{$\begin{array}{l}\text { Soil water content } \\
\qquad\left(\mathrm{m}^{3} \mathrm{~m}^{-3}\right)\end{array}$} & \multirow{2}{*}{$\begin{array}{l}\text { TAW } \\
(\mathrm{mm})\end{array}$} \\
\hline & & Sand & Silt & Clay & $\theta_{\mathrm{FC}}$ & $\theta_{\mathrm{PWP}}$ & \\
\hline $0.0-0.10$ & 1.41 & 35 & 44 & 21 & 0.27 & 0.12 & 15 \\
\hline $0.10-0.25$ & 1.37 & 37 & 45 & 18 & 0.28 & 0.12 & 24 \\
\hline $0.25-0.55$ & 1.38 & 36 & 45 & 19 & 0.30 & 0.12 & 54 \\
\hline $0.55-0.85$ & 1.31 & 20 & 32 & 48 & 0.42 & 0.19 & 69 \\
\hline
\end{tabular}

$\rho \mathrm{b}=$ soil bulk density; $\theta_{\mathrm{FC}}=$ soil water content at field capacity; $\theta_{\mathrm{PWP}}=$ soil water content at wilting point $(-1500 \mathrm{kPa}) ; \mathrm{TAW}=$ total available soil water.

Two plants per plot were used for leaf area index (LAI) and plant height observations, as well as the identification of the main phenological stages. Nondestructive individual leaf area (LA) were measures at the central leaf and then the trifoliate area was estimated using the linear equation approach $(\mathrm{LA}=2.0185 \mathrm{LW})$, proposed by Richter et al. (2014), where L and W are the length and width of the central leaflet. The plant leaf area was further calculated by the sum of the individual leaves. Leaf area index (LAI) was then calculated by the ratio of the LA $\left(\mathrm{m}^{2}\right.$ leaf) and the soil surface occupied by each individual plant ( $\mathrm{m}^{2}$ soil area). The beginning and end of the main crop stages were observed following Allen et al. (1998). 
The soil water content $\left(\theta, \mathrm{m}^{3} / \mathrm{m}^{3}\right)$ was measured hourly using a set of FDR probes, model CS616 Campbell Scientific, Inc.), installed at 0.0-0.10, 0.10-0.25, 0.25-0.55, and $0.55-0.85 \mathrm{~m}$ layers, which totaled 4 sensors per plot. Daily soil moisture $(\theta)$ was considered from the last measurement taken from the data logger at each sensor $(23$ hours). The daily available soil water (ASW, mm) was computed for each soil layer by the product of the $\theta$ by the thickness of the soil layer, in $\mathrm{mm}$, and then subtracted from the water depth at wilting point. The TAW up to $0.85 \mathrm{~m}$ soil depth was assumed to be $162 \mathrm{~mm}$.

A drip irrigation system, with pressure compensating drip tubes with a diameter of $16 \mathrm{~mm}$ was used. Emitter spacing along the tube was $0.2 \mathrm{~m}$ and the rows were spaced $0.50 \mathrm{~m}$ apart, between two rows of plants. Drippers presented a flow rate of $0.9 \mathrm{~L} \mathrm{hour}^{-1}$, at $100 \mathrm{kPa}(\sim 10 \mathrm{mca})$, which results in an application rate of $6.2 \mathrm{~mm} \mathrm{hour}^{-1}$. Prior to the application of the treatments (at 30 days after sowing, DAS), all plots were maintained with the same irrigation depth. The gross irrigation depths ranged from 7 to $24 \mathrm{~mm}$, and the coefficient of uniformity (Merriam \& Keller, 1978), measured in all plots, was $85 \%$.

Modeling soil water balance, estimating water productivity, irrigated water productivity, yield, and the analysis of production costs
The SIMDualKc model, described by Rosa et al. (2012), was used to simulate the daily ASW variation in the root zone, as well as the real or actual crop evapotranspiration $\left(\mathrm{ET}_{\mathrm{c}}\right.$ act $)$, the maximum $\left(\mathrm{T}_{\mathrm{c}}\right)$ and actual crop transpiration $\left(\mathrm{T}_{\mathrm{c} \text { act }}\right)$, and the soil water evaporation $\left(E_{s}\right)$. The model adopts the dual crop coefficient approach proposed by Allen et al. (1998).

Input data needed for the simulation are: soil water content at field capacity $\left(\theta_{\mathrm{FC}}\right)$ and wilting point, $\left(\theta_{\mathrm{WP}}\right)$, used in the TAW computation, percent fraction of sand, silt, and clay (Table 1), as well as the readily available water (RAW), the readily evaporable and total evaporable water (REW and TEW, mm) in the plant root zone (Ze). Weather data, such as the $\mathrm{ET}_{\mathrm{o}}\left(\mathrm{mm} \mathrm{dia}^{-1}\right)$, precipitation $(\mathrm{mm})$, minimum relative humidity $\left(\mathrm{RH}_{\min }, \%\right)$, and wind speed measured at $2 \mathrm{~m}$ height $\left(\mathrm{u}_{2}, \mathrm{~m} \mathrm{~s}^{-1}\right)$ are also required for the simulation process. Crop data, like the crop type, initial and final dates of each crop development stage (Table 2), LAI, plant height (h), and plant root depth $\left(Z_{r}\right)$ were included. The initial plant height assumed in the model calibration was $0.10 \mathrm{~m}$. From the irrigation management, necessary input data are the irrigation depths for each date and the irrigation system that was used, in order to calculate the soil fraction wetted $\left(f_{w}\right)$. As a trickle system with tubes spaced at $0.50 \mathrm{~m}$, the $\mathrm{f}_{\mathrm{w}}$ used was 0.8 .

TABLE 2. Dates and duration of the main growth stages of soybean submitted to different irrigation strategies, during the 2014/15 crop growing season.

\begin{tabular}{cccccc}
\hline Treatment & Initial date & Crop development & Mid-season & Crop senescence & Harvest \\
\hline 75 & $30 / 11(19)$ & $19 / 12(27)$ & $15 / 01(57)$ & $13 / 03(19)$ & $01 / 04$ \\
64 & $30 / 11(20)$ & $20 / 12(25)$ & $14 / 01(53)$ & $08 / 03(16)$ & $24 / 03$ \\
60 & $30 / 11(20)$ & $20 / 12(25)$ & $14 / 01(48)$ & $03 / 03(17)$ & $20 / 03$ \\
50 & $30 / 11(20)$ & $20 / 12(24)$ & $13 / 01(48)$ & $02 / 03(16)$ & $18 / 03$ \\
\hline
\end{tabular}

Values between brackets correspond to the length of the stage, in days.

The initial values of the basal crop coefficient $\left(\mathrm{K}_{\mathrm{cb}}\right)$ were calculated from the observed data of LAI and plant height, as proposed by Allen \& Pereira (2009):

$$
\mathrm{K}_{\mathrm{cb}}=\mathrm{K}_{\mathrm{c}} \min +\mathrm{K}_{\mathrm{d}}\left(\mathrm{K}_{\mathrm{cb}} \text { full- } \mathrm{K}_{\mathrm{c}} \min \right)
$$

Where:

$K_{d}$ is the density coefficient, $K_{c b}$ full is the $K_{c b}$ estimated during peak plant growth, when the crops almost fully covered the soil (when IAF $>3$ ), and $\mathrm{K}_{\mathrm{c}}$ min expresses the minimum basal $\mathrm{K}_{\mathrm{c}}$ bare soils, $\mathrm{K}_{\mathrm{cb}}=0.15$ being used for typical agricultural crops. Meanwhile, the $\mathrm{K}_{\mathrm{cb}}$ full is estimated from the $\mathrm{K}_{\mathrm{cb}}$ values tabulated in the FAO56 bulletin, adjusted to $\mathrm{RH}_{\min }$ at $45 \%$ and average wind speed $\left(u_{2}\right)$ at $2 \mathrm{~m} \mathrm{~s}^{-1}$. The $K_{d}$ was estimated as a function of the LAI, but it can be estimated as a function of the fraction of ground covered by the vegetation when LAI has not been measured:

$$
\mathrm{K}_{\mathrm{d}}=\left(1-\mathrm{e}^{[-0,7 \mathrm{IAF}]}\right)
$$

The depletion fraction for no stress $(p)$ was determined as recommended by Allen et al. (1998); the thickness of the evaporable layer $\left(Z_{\mathrm{e}}\right)$ assumed was $0.15 \mathrm{~m}$, and the parameters that characterize soil evaporation (REW) were obtained from soil texture in the upper soil layer (Table 1). The surface runoff (RO) and deep percolation (DP) parameters $\left(a_{D}\right.$ and $\left.b_{D}\right)$ were adjusted to the values calibrated by Paredes et al. (2018).

The SIMDualKc model calibration procedure aimed to obtain crop parameters $\left(\mathrm{K}_{\mathrm{cb}}\right.$ and $p$ for each crop growth stage), the soil evaporation parameters $\left(Z_{e}, T E W\right.$, and REW), and DP data that minimized the deviations between the observed and simulated available soil water data (ASW) in the root zone. In this study, $75 \%$ of TAW treatment was used to calibrate the model while the other treatments were used to validate the SIMDualKc model.

Water productivity (WP, $\mathrm{kg} \mathrm{m}^{-3}$ ), which establishes the ratio between the actual crop yield $\left(\mathrm{Y}_{\mathrm{a}}, \mathrm{Kg}\right)$ and the total water used for this achieved yield (TWU, $\mathrm{m}^{3}$ ), was computed by $\mathrm{WP}=\mathrm{Y}_{\mathrm{a}} / \mathrm{TWU}$. The TWU included rainfall, the water depth applied by irrigation, as well as the change in available soil water $(\triangle \mathrm{ASW})$ throughout the growing season. The irrigated water productivity, which considers only the consumptive use of irrigated water $\left(\mathrm{WP}_{\mathrm{I}}, \mathrm{kg} \mathrm{m}^{-3}\right)$, was computed by the ratio of the actual yield $\left(\mathrm{Ya}, \mathrm{Kg} \mathrm{m}^{-3}\right)$ and the given irrigation water depth (IWU, $\mathrm{Kg} \mathrm{m}^{-3}$ ), as $\mathrm{WP}_{\mathrm{I}}$ $=\mathrm{Y}_{\mathrm{a}} / \mathrm{IWU}$.

The soybean grain yield was determined at physiological maturity (R9 stage) by manually harvesting the three center rows of each plot (usable area of $4.5 \mathrm{~m}^{2}$ ), correcting the data to $\mathrm{Kg} \mathrm{ha}^{-1}$ after adjusting the seed moisture content to $13 \%$. The yield prediction, aiming to 
assess the soybean response to the various levels of deficits, was performed by coupling the SIMDualKc model with the Stewart's water-yield model (Stewart et al., 1977), where it is assumed that a relative loss of yield varies linearly with the potential $\left(\mathrm{T}_{\mathrm{c}}\right)$ and actual $\left(\mathrm{T}_{\mathrm{c}}\right.$ act $)$ crop transpiration, according to [eq. (3)]:

$$
1-\frac{Y_{a}}{Y_{m}}=K_{y}\left(1-\frac{T_{c a c t}}{T_{c}}\right)
$$

Where:

$\mathrm{Y}_{\mathrm{m}}$ and $\mathrm{Y}_{\mathrm{a}}$ are the maximum and the actual yield $(\mathrm{kg}$ $\left.\mathrm{ha}^{-1}\right)$, respectively, for the maximum and the actual crop transpiration ( $\mathrm{T}_{\mathrm{c}}$ and $\mathrm{T}_{\mathrm{c} \text { act }}$ ) obtained from the SIMDualKc simulations. Here the $\mathrm{Y}_{\mathrm{m}}$ corresponded to the yield achieved on treatment with maximum water replacement. The $\mathrm{K}_{\mathrm{y}}$, which is the crop yield response factor to water, used was 0.85 , as proposed by Doorenbos \& Kassam (1979).

The analysis of production costs and grain prices over the years was carried out using as an example an average property at the Planalto Médio Region of Rio Grande do Sul State. The currency used for the computation was the Brazilian real. The total costs were split into the operating costs for the mechanized production of high yielding soybeans $(4,600 \mathrm{~kg} \mathrm{ha}-1)$ and the costs related to irrigation (the cost to apply the irrigation depth in systems powered by diesel-electric or just electric, depreciation, and equipment maintenance). To compute the total cost per hectare $\left(\mathrm{T}_{\text {cost }}\right)$, the following expenses were used: investment in buying equipment (center-pivot irrigation system) (IS $\left.\mathrm{S}_{\text {cost }}\right)$, pro-rata over 10 years; fixed costs $\left(\mathrm{F}_{\text {cost }}\right)$ per hectare, due to equipment, land value, etc.; and variable costs per hectare $\left(\mathrm{V}_{\text {cost }}\right)$, which correspond to expenses related to actual production (seeds, fertilizers, phytosanitary products, etc.), according to [eq. (4)].

$$
T_{\text {cos } t}=I S_{\text {cos } t}+I_{\text {cos } t}+F_{\text {cos } t}+V_{\text {cos } t}
$$

The gross revenue (GR) was computed by the product of the yield achieved in each treatment $\left(\mathrm{Kg} \mathrm{ha}^{-1}\right)$ and the commodity price $(\mathrm{R} \$)$ obtained at harvest time. Further, the operating revenue per hectare was computed $\left(\mathrm{OR}_{\mathrm{ha}}\right)$, which expresses the difference between the $\mathrm{T}_{\text {cost }}$ minus the gross revenue after selling the product, according to [eq. (5)].

$$
O R_{h a}=T_{\text {cost }}-G R
$$

Farmer's net income was calculated based on three possible scenarios of commodity prices at soybean harvesting time, the average market price at the time ( $\mathrm{R} \$$ $60.00)$, a selling price above the average ( $R \$ 70.00)$ and a selling price below ( $\mathrm{R} \$ 50.00)$, respectively.

\section{Statistical analysis}

A set of statistical indicators were used to assess the model capability in comparing the observed and simulated data, following those used by Pereira et al. (2015) and Ávila et al. (2017), which are: a linear regression forced through the origin $\left(b_{0}\right)$; the coefficient of determination of the linear regression $\left(\mathrm{R}^{2}\right)$, the root mean square error (RMSE), percent bias of estimation (PBIAS), and the modeling efficiency (EF).

\section{RESULTS AND DISCUSSION}

Figure 1 shows the variation of ASW during the $2014 / 15$ soybean growing season. In the initial stage (up to $10 \%$ of LAI), ASW remained above $85 \%$ of the TAW, in all treatments. With the restriction of available water, ASW decreased until it exceeded the RAW line, from 100, 69, 61, and 55 DAS, for treatments $75 \%, 64 \%, 60 \%$, and $50 \%$ of TAW, respectively. The water deficit occurs when the ASW is less than the established critical limit, in this case, the RAW line. The $p$-value, necessary for the RAW computation (RAW = TAW.p), followed limits recommended by Allen et al. (1998) for soybean and also tested by Wei et al. (2015) and Gimenez et al. (2017) for this same crop. 


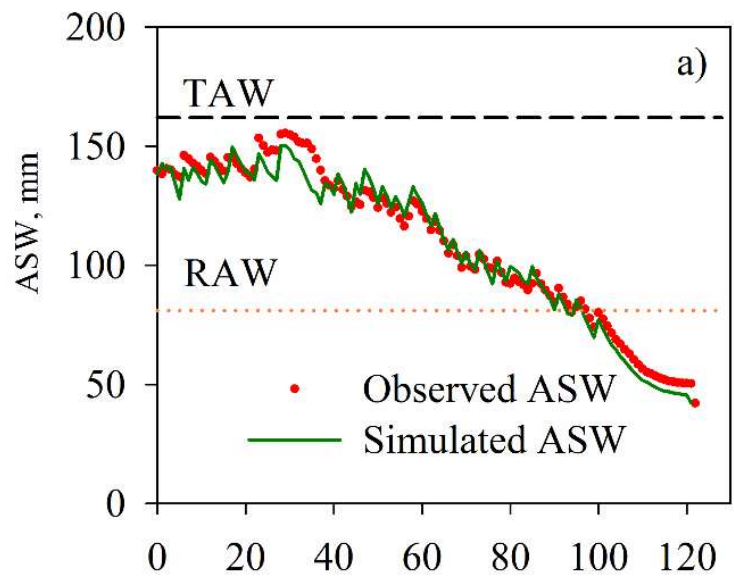

Days after sowing, DAS

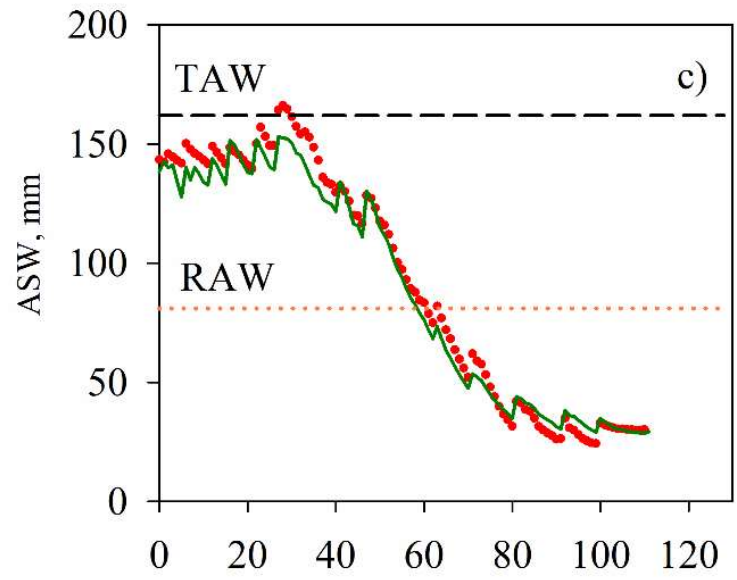

Days after sowing, DAS

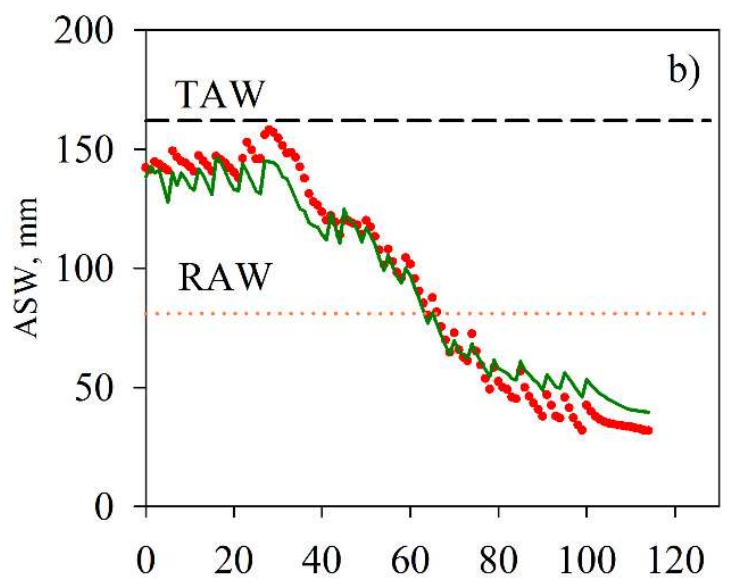

Days after sowing, DAS

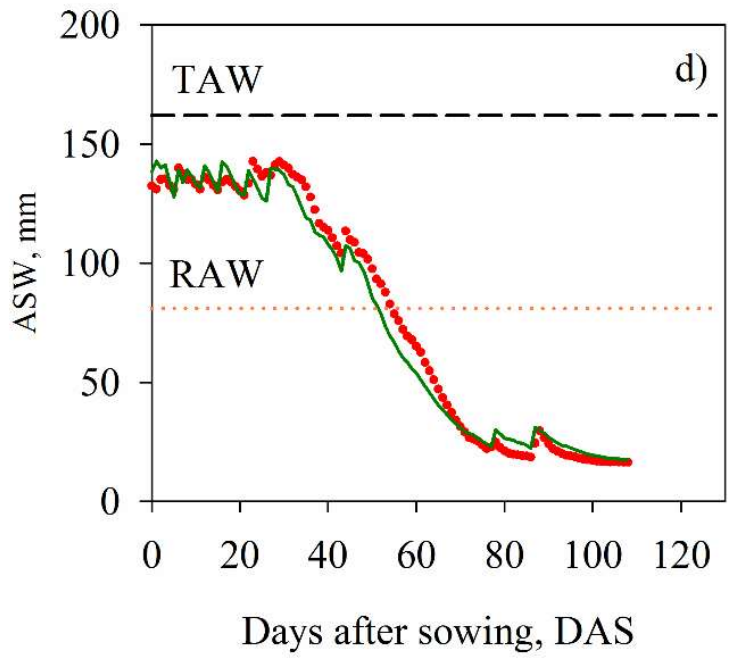

FIGURE 1. Daily observed (dots) and simulated (lines) ASW variation under four irrigation treatments: 75\% (a), 64\% (b), 60\% (c), and $50 \%$ of the TAW (d). The horizontal traced and dotted lines represent the total soil available water (---, TAW, mm) and the readily soil available water $(. . ., \mathrm{RAW}, \mathrm{mm})$.

Moreover, in this study, the drip lines were arranged between two rows of plants, but not necessarily near or over an FDR probe. Although the model has adequately simulated the soil water content measured by these probes, the irrigation depths applied $(13 \mathrm{~mm} ; \pm 3.5)$ resulted in a progressive deficit in the crop root zone, which is clearly shown by the ASW below the RAW limit.

The goodness-of-fit indicators for the ASW (Table 3 ) demonstrate that the simulation can be considered good to very good, with values of $b_{0}$ ranging from 0.96 to 0.98 and $R^{2} \geq 0.98$. The errors of estimations were also small, as RMSE ranged from 5.29 to $8.29 \mathrm{~mm}$, representing only $5.18 \%$ of the TAW. In addition, the EF $>0.97$ indicates that the variance of the residual's estimation was much smaller than the variance of the observed ASW data. The PBIAS indices remained low $(0.9$ and $3.65 \%)$, indicating that the simulated ASW data approached those observed, with a slight underestimation. Good performance of the model was also reported by Wei et al. (2015) and Gimenez et al. (2017) for soybeans.

TABLE 3. Goodness-of-fit indicators of the SIMDualKc model to the ASW observations.

\begin{tabular}{cccccc}
\hline \multirow{2}{*}{ Treatments } & $\mathrm{b}_{0}$ & $\mathrm{R}^{2}$ & $\mathrm{RMSE}$ & PBIAS & EF \\
\cline { 4 - 5 } & & & $(\mathrm{mm})$ & 1.60 & 0.97 \\
64 & 0.98 & 0.98 & 5.29 & 0.90 & 0.97 \\
60 & 0.96 & 0.99 & 8.29 & 3.65 & 0.98 \\
50 & 0.96 & 0.99 & 6.55 & 2.28 & 0.98 \\
\hline
\end{tabular}

$\mathrm{b}_{0}$ : Linear regression coefficient; $\mathrm{R}^{2}$ : determination coefficient; PBIAS: percent bias of estimation; RMSE: root mean square error; EF: modeling efficiency. 
The initial and calibrated basal crop coefficients $\left(\mathrm{K}_{\mathrm{cb}}\right)$ for the conditions established in this study are presented in Table 4. In the treatments submitted to moderate and severe deficit (Figures $2 \mathrm{c}$ and d), the soil water deficit showed up at the beginning of the mid-season, i.e., the actual basal crop coefficient lowered the potential $\mathrm{K}_{\mathrm{cb}}\left(\mathrm{K}_{\mathrm{cb} \text { act }}<\mathrm{K}_{\mathrm{cb}}\right)$. In this stage, when in no-stress conditions, the water consumption can exceed $6.0 \mathrm{~mm} \mathrm{dia}^{-1}$. Peaks of the $K_{c b}$ act values can be observed after every irrigation event. A reduction in the crop cycle was also observed in these treatments, shortening the mid-season and accelerating the crop senescence, anticipating the harvest, as presented in Table 2 .

TABLE 4. Initial and calibrated values of basal crop coefficients $\left(\mathrm{K}_{\mathrm{cb}}\right)$, depletion fraction for no stress $(p)$, evaporable soil layer, run-off, and deep percolation.

\begin{tabular}{|c|c|c|}
\hline Parameters & Initial & Calibrated \\
\hline \multicolumn{3}{|l|}{ Crop } \\
\hline $\mathrm{K}_{\mathrm{cb} \text { ini }}$ & 0.15 & 0.15 \\
\hline $\mathrm{K}_{\mathrm{cb} \text { mid }}$ & 1.10 & 1.00 \\
\hline $\mathrm{K}_{\mathrm{cb} \text { end }}$ & 0.30 & 0.30 \\
\hline $\mathrm{p}_{\text {ini, }}, \mathrm{p}_{\text {mid }}$ and $\mathrm{p}_{\mathrm{end}}$ & 0.50 & 0.50 \\
\hline \multicolumn{3}{|l|}{ Soil evaporation } \\
\hline REW (mm) & 10 & 10 \\
\hline TEW (mm) & 39 & 39 \\
\hline $\mathrm{Ze}(\mathrm{m})$ & 0.15 & 0.15 \\
\hline \multicolumn{3}{|l|}{ Run-off and deep percolation } \\
\hline $\mathrm{CN}$ & 75 & 75 \\
\hline$a_{D}$ & 408 & 401.5 \\
\hline $\mathrm{b}_{\mathrm{D}}$ & -0.017 & -0.017 \\
\hline
\end{tabular}

* $\mathrm{K}_{\mathrm{cb}}$ : basal crop coefficients (for the initial, mid-season, and end-season); p: depletions (for the initial, mid-season, and end-season); REW: readily evaporable water; TEW: total evaporable water; $\mathrm{Z}_{\mathrm{e}}$ : soil evaporable layer; $\mathrm{CN}$ : number curve; $\mathrm{a}_{\mathrm{D}}$ and $\mathrm{b}_{\mathrm{D}}$ : parameters of the percolation equations proposed by Liu et al., (2006).

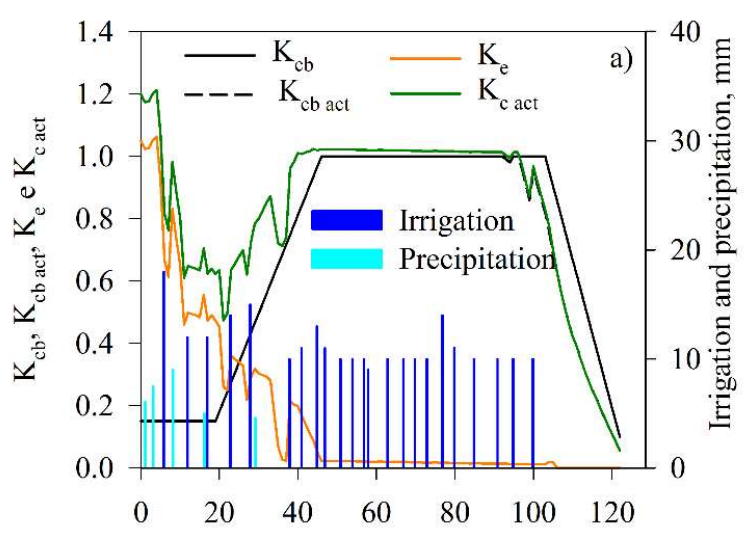

Days after sowing, DAS

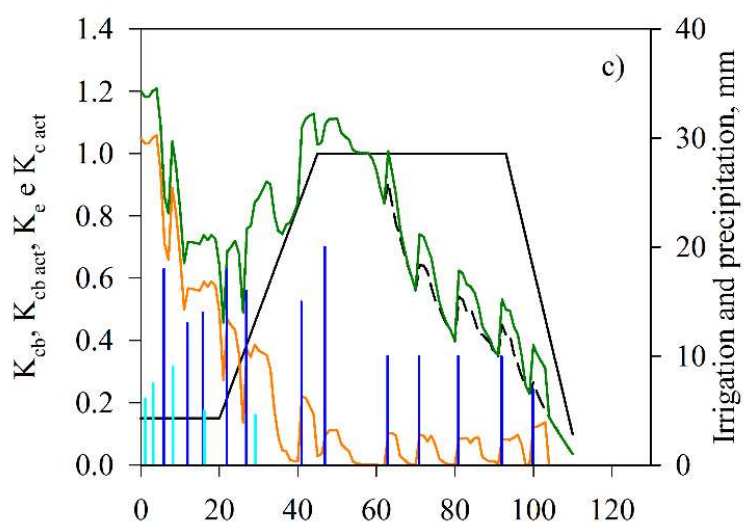

Days after sowing, DAS
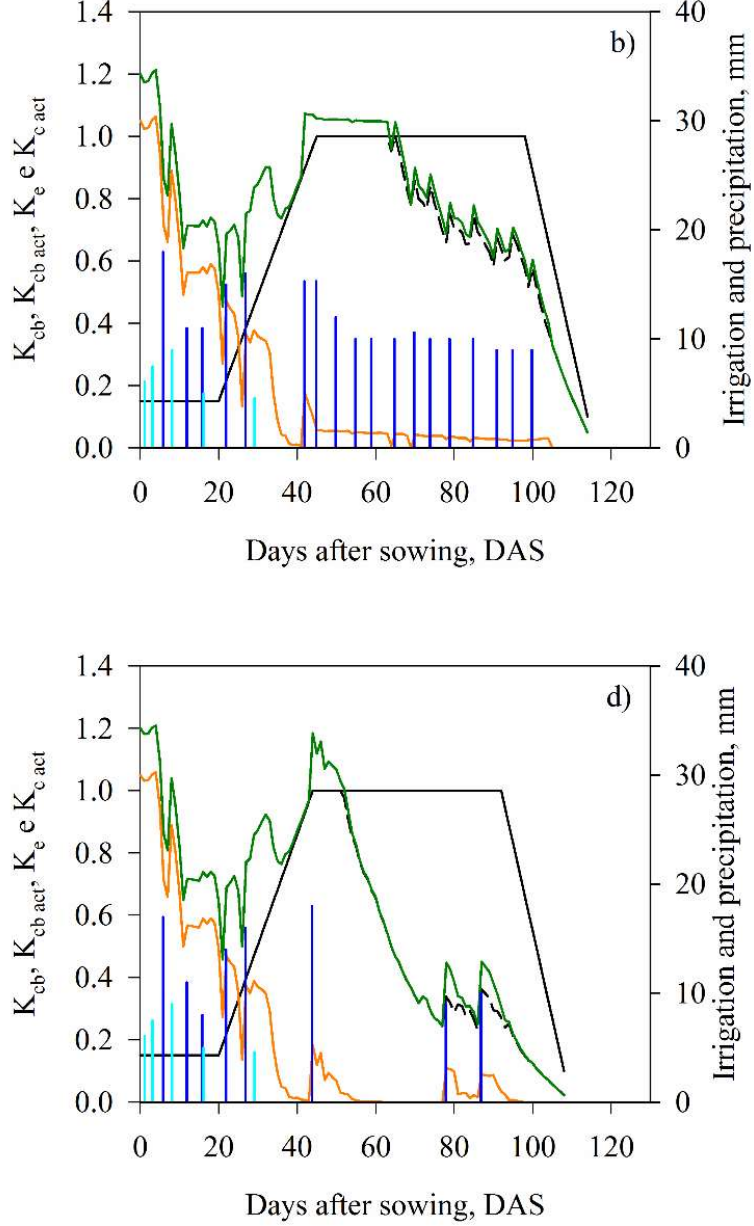

FIGURE 2. Seasonal variation of the evaporation coefficient $\left(\mathrm{K}_{\mathrm{e}}\right)$, basal crop coefficient $\left(\mathrm{K}_{\mathrm{cb}}\right)$, actual basal crop coefficient $\left(\mathrm{K}_{\mathrm{cb}}\right.$ act), and single crop coefficient $\left(\mathrm{K}_{\mathrm{c}}\right)$, including precipitation and applied irrigations, during the soybean growing season, for $75 \%$ (a), 64\% (b), 60\% (c), and 50\% (d) of the TAW treatments. Santa Maria-RS, 2019. 
In studies carried out in similar climate conditions, Gimenez et al. (2017) validated $\mathrm{K}_{\mathrm{cb}}$ values of 1.10 for the mid-season stage and 0.35 for the $\mathrm{K}_{\mathrm{cb}}$ end. Wei et al. (2015) obtained $\mathrm{K}_{\mathrm{cb}}$ of 1.05, while Odhiambo \& Irmak (2012) found values of $0.15,1.08$, and 0.33 , for the $\mathrm{K}_{\mathrm{cb} \text { ini }}, \mathrm{K}_{\mathrm{cb} \text { mid, }}$, and $\mathrm{K}_{\mathrm{cb}}$ end, respectively, initial, mid-season, and endseason, according to FAO56 (Allen et al., 1998). The $\mathrm{K}_{\mathrm{cb} \text { end }}$ is strongly related to the moment of harvest; when the crop is harvested close to physiological maturation, higher values of the $\mathrm{K}_{\mathrm{cb} \text { end }}$ will be obtained. However, when the harvest is carried out with lower grain moisture content, the $\mathrm{K}_{\mathrm{cb} \text { end }}$ is smaller, since it is related to the photosynthetically active leaf area, i.e., the LAI.

The variation of the single $\mathrm{K}_{\mathrm{c}}\left(\mathrm{K}_{\mathrm{e}}+\mathrm{K}_{\mathrm{cb}}\right)$ during the whole soybean season can also be used to verify the occurrence or not of water stress, especially in the peak of water consumption. When the $\mathrm{K}_{\mathrm{c}}$ act deviates from the potential $K_{c b}$ curve and, if there is no $E_{s}$, since the crop canopy practically closes the inter-rows, stress occurred. Thus, the increase observed in the $\mathrm{K}_{\mathrm{c} \text { act }}$ (Figures $2 \mathrm{~b}$, c, and d) is justified by irrigation events, raising $\mathrm{K}_{\mathrm{e}}$ and, consequently, $E_{s}$, while the decrease in $K_{c}$ act is directly related to the increase in the stress coefficient $\left(\mathrm{K}_{\mathrm{s}}\right)$, as was also observed by Payero et al. (2009). Payero \& Imark (2013) observed $K_{c}$ values ranging from 1.07 to 1.33 in Nebraska. These authors determined $\mathrm{ET}_{\mathrm{c}}$ measuring energy fluxes using an "eddy covariance" station, deriving the $\mathrm{K}_{\mathrm{c} \text { 's }}$ from $\mathrm{ET}_{\text {ref. }}$.

Greater $E_{\mathrm{s}}$ occurred for the $60 \%$ of TAW treatment; although $E_{s}$ is energy-dependent and depends on soil moisture, the greater $\mathrm{E}_{\mathrm{s}}$ (Table 5) might be related to the lower LAI, since LAI reduced significantly in treatments with the greater deficit, during the flowering and grain filling stages. After 90 DAS, LAI was less than four in these treatments, a factor that contributed to the increase in $E_{s}$ at the final stage. Wei et al. (2015), working with soybean in China, measured and simulated the $E_{s}$ throughout the soybean cycle, and observed peaks right after a rain or irrigation event. It cannot be dismissed, either, that the model underestimated $\mathrm{E}_{\mathrm{s}}$ when the crop completely covered the soil (which occurred in the treatment maintained at $75 \%$ of TAW) since most of the water extracted from the surface layer in these conditions is attributed to transpiration, a condition different from that when losses occur only through evaporation (Paredes et al., 2015). The variation on $E_{s}$ and $T_{c}$ components are in agreement with studies done by Paredes et al. (2018), Wei et al. (2015), and Pereira et al. (2015), with greater expression of $E_{s}$ in the first crop stage, when the soil is mostly uncovered and LAI is minimal $(<10 \%)$. As crops grow, there is a decrease in $\mathrm{E}_{\mathrm{s}}$ and an increase in $\mathrm{T}_{\mathrm{c}}$ values.

TABLE 5. Components of the soil water balance computed by the SIMDualKc model, and predicted and observed grain yield for the four levels of deficit.

\begin{tabular}{|c|c|c|c|c|c|c|c|c|c|c|}
\hline \multirow[b]{2}{*}{ Treatments } & I & $\mathrm{P}$ & $\Delta \mathrm{ASW}$ & TWU & $\mathrm{ET}_{\mathrm{c} \text { act }}$ & $\mathrm{T}_{\mathrm{c} \text { act }}$ & $\mathrm{E}_{\mathrm{s}}$ & $\mathrm{E}_{\mathrm{s}} / \mathrm{ET}_{\mathrm{c} \text { act }}$ & \multicolumn{2}{|c|}{ Yield } \\
\hline & & & & $(\mathrm{mm})$ & & & & $(\%)$ & $\begin{array}{c}\text { Actual } \\
\left(\mathrm{Mg} \mathrm{ha}^{-1}\right)\end{array}$ & $\begin{array}{l}\text { Predicted } \\
\quad\left(\mathrm{Mg} \mathrm{ha}^{-1}\right)\end{array}$ \\
\hline 75 & 260 & 32 & 116 & 408 & 392 & 307 & 85 & 22 & 5.7 & 5.5 \\
\hline 64 & 212 & 32 & 121 & 365 & 348 & 253 & 96 & 32 & 4.9 & 4.5 \\
\hline 60 & 161 & 32 & 132 & 325 & 309 & 209 & 100 & 32 & 4.3 & 3.5 \\
\hline 50 & 103 & 32 & 144 & 279 & 263 & 170 & 92 & 35 & 3.8 & 2.9 \\
\hline
\end{tabular}

$\mathrm{I}=$ irrigation, $\mathrm{P}=$ precipitation, $\triangle \mathrm{ASW}=$ variation in available soil water, throughout the season; $\mathrm{TWU}=$ total water used, $\mathrm{ET}_{\mathrm{c}}$ act actual crop evapotranspiration, $\mathrm{T}_{\mathrm{c} \text { act }}=$ actual crop transpiration, $\mathrm{E}_{\mathrm{s}}=$ soil evaporation; $\mathrm{Y}_{\mathrm{a}}=$ actual (observed) yield; $\mathrm{E}_{\mathrm{s}} / \mathrm{T}_{\mathrm{c}}$ act $=$ ratio between $\mathrm{E}_{\mathrm{s}}$ and $\mathrm{ET}_{\mathrm{c}}$.

Significant water losses by $\mathrm{E}_{\mathrm{s}}$ were observed, mainly due to the absence of surface crop residues. The ratio between the $\mathrm{E}_{\mathrm{s}} / \mathrm{ET}_{\mathrm{c}}$ act indicates lower losses in treatments maintained at $75 \%$ and $64 \%$ of TAW, probably due to the higher LAI in these treatments compared to those with more severe water deficit. Gimenez et al. (2017) observed evaporation losses of $16 \%$ in relation to $\mathrm{ET}_{\mathrm{c}}$, for soybean sown in the first half of November, in Uruguay.

The reduction in $\mathrm{E}_{\mathrm{s}}$ can result in water-saving from reduced irrigation during the season, and consequent reduction in irrigation costs. In soils submitted to conventional tillage or with a reduced amount of mulch on the soil surface, the upper soil layer dries quickly due to the action of meteorological factors. In these conditions, after rain or irrigation, the daily water loss by $\mathrm{E}_{\mathrm{s}}$ can increase up to $15 \%$ higher than $\mathrm{ET}_{\mathrm{o}}$ (Allen et al., 1998). Thus, frequent irrigation is required in order to obtain adequate germination and crop establishment in the early stages. From the moment the crop canopy completely shadows the surface (IAF> 2.7), losses by $\mathrm{E}_{\mathrm{s}}$ drop to zero or minimum.

The consumptive water used during the whole season ranged from 408 to $279 \mathrm{~mm}$, for the treatments maintained at $75 \%$ and $50 \%$ of TAW, respectively.
However, mild to severe water stress was observed in all treatments, as shown in Figures 1 and 2. The $\mathrm{ET}_{\mathrm{c}}$ values found in this study were relatively low when compared to the yield obtained. Although the reduction in observed yield was significant, it was proportional to the reduction in the

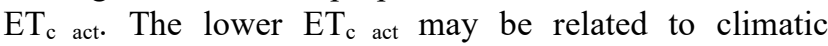
conditions, with the minimum relative humidity higher for most days $\left(\mathrm{RH}_{\min }>45 \%\right.$ for $90 \%$ of the days), resulting in a smaller $\mathrm{K}_{\mathrm{c}}$. The average $\mathrm{ET}_{\mathrm{o}}$ during the crop cycle was 4.15 $\mathrm{mm} \mathrm{day}^{-1}$, for an $\mathrm{ET}_{\mathrm{c} \text { act }}$ of $3.14,3.01,2.65$, and $2.41 \mathrm{~mm}$ day $^{-1}$, respectively, for treatments $75 \%, 64 \%, 60 \%$, and $50 \%$ of TAW. Similar results were observed by Moreira et al. (2015), who worked with soybean in southern Brazil, obtaining a total $\mathrm{ET}_{\mathrm{c}}$ of $410 \mathrm{~mm}$ (average of $3.20 \mathrm{~mm} \mathrm{day}^{-1}$ ).

\section{Water productivity and economic return}

A comparison between the observed $\left(\mathrm{Y}_{\mathrm{a}}\right)$ and predicted yield, $\mathrm{Mg} \mathrm{ha}^{-1}$, and the economic return for the different irrigation strategies are presented in Figures $3 \mathrm{a}$ and 3 b. Applying the modified Stewart's model (from equation 3 ) adopting a $\mathrm{Ky}=0.85$, resulted in a good yield prediction, with a slight tendency of underestimation $\left(b_{0}=0.89\right)$, with 
deviations ranging from $3 \%$ to $25 \%$, between observed and predicted yield. Cera et al. (2017) found a similar variation using the CROPGRO-Soybean (RMSE $=0.9 \mathrm{Mg} \mathrm{ha}^{-1}$ ). The yield response factor $(\mathrm{Ky})$ found in this study was similar to that recommended by Doorenbos \& Kasssam (1979), but significantly lower than those found by Giménez et al. (2017) for soybean in Uruguay, indicating that soybeans

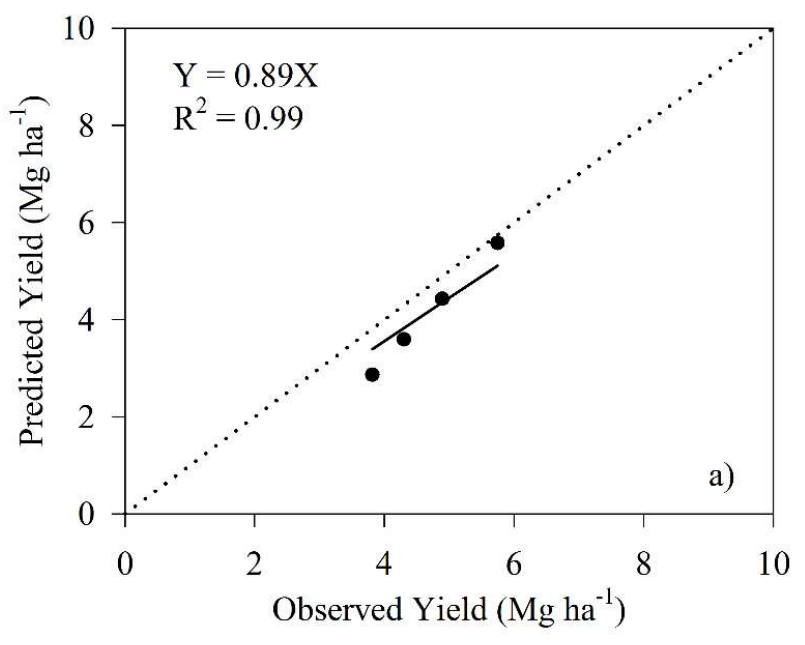

better tolerated water deficiency under the conditions in which the experiment was carried out. WP did not differ between treatments $\left(1.4 \mathrm{~kg} \mathrm{~m}^{-3}\right)$, however, WPI was higher in treatments with greater deficit, 2.67 and $3.75 \mathrm{~kg} \mathrm{~m}^{-3}$, for $60 \%$ and $50 \%$ of TAW, respectively, while the treatments with higher irrigation depths resulted in a WPI of $2.3 \mathrm{~kg} \mathrm{~m}^{-3}$.

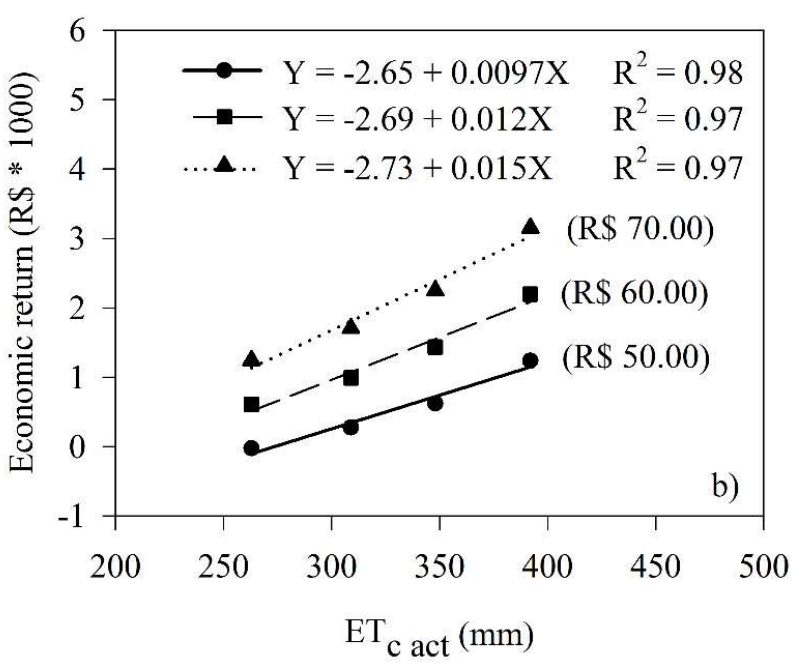

FIGURE 3. Relation between observed $\left(\mathrm{Y}_{\mathrm{a}}\right)$ and predicted yield (a), and economic return (b) of soybean submitted to different levels of deficit.

The best economic return was obtained for the treatment maintained at $75 \%$ of the TAW, in all price scenarios, with a liquid income above 3,000 reais per hectare (Figure $3 \mathrm{~b}$ ), with a marketing price of $\mathrm{R} \$ 70.00$ per $60 \mathrm{~kg}$ bag. However, with a selling price of $\mathrm{R} \$ 50.00$, the profitability obtained was slightly higher than 1,000 reais per hectare, representing a reduction in economic return of about $60 \%$. When analyzing the various irrigation depths, and with a selling price of $\mathrm{R} \$ 60.00$, the reduction in profitability was close to $72 \%$, with values of $\mathrm{R} \$ 2,194.60$ and $\mathrm{R} \$ 608.80$ (difference of $\mathrm{R} \$ 1,585.80$ ), from the treatment of $75 \%$ to $50 \%$ of the TAW. For the conditions observed, even in severe deficit (50\% of TAW), the ER would still be positive. It would appear that what most affects the economic return on irrigation investments is the water depth applied, followed by the commodity prices.

\section{CONCLUSIONS}

The basal crop coefficient $\left(\mathrm{K}_{\mathrm{cb}}\right)$ calibrated and validated for the initial, mid-season, and end-season stages was $0.15,1.00$, and 0.30 , respectively, for soybean cultivated in a conventional tillage system. Transpiration $\left(T_{c}\right)$ showed great seasonal variability, while soil evaporation $\left(E_{\mathrm{s}}\right)$ was greater in the initial phase and with great response to events of soil wetting.

Grain yield decreased linearly with increasing water deficit, with a reduction of $34 \%$ between the treatment maintained at $75 \%$ of the TAW compared to that maintained at $50 \%$ of the TAW. The treatment maintained at $75 \%$ of the TAW, associated with a selling price of $\mathrm{R} \$ 70.00$, resulted in a higher economic return ( $\mathrm{R} \$ 3,151.80$ per hectare). On the other hand, for more severe deficits and a commodity price of $\mathrm{R} \$ 50.00$, there was a negative return of R\$ -27.10 per hectare, values that contribute to decision making about which irrigation management to adopt. The use of deliberate water deficit in soybeans can result in water savings, which optimized the water stored in the soil, resulting in better WPI.

\section{REFERENCES}

Allen RG, Pereira LS (2009) Estimating crop coefficients from fraction of ground cover and height. Irrigation Science 28:17-34. DOI: https://doi.org/10.1007/s00271-009-0182-z

Allen RG, Pereira LS, Raes D, Smith M (1998) Crop evapotranspiration. Guidelines for computing crop water requirements, FAO irrigation and drainage paper 5. Rome, FAO, 300p.

Allen RG, Pereira LS, Smith M, Raes D, Wright JL (2005) FAO-56 dual drop coefficient method for estimating evaporation from soil and application extensions. Journal of Irrigation and Drainage Engineering 131:2-13. DOI: https://doi.org/10.1061/(ASCE)0733-9437(2005)131:1(2)

Ávila VS, Petry MT, Carlesso R, Martins JD, González MG, Oliveira ZB, Nunes JNV, Menegaz ST (2017) Simulation of soil water balance and partitioning of evapotranspiration of maize grown in two growing seasons in Southern Brazil. Ciência Rural 47(12):e20160998. DOI: https://dx.doi.org/10.1590/0103-8478cr20160998

Cera JC, Streck NA, Yang H, Zanon AJ, de Paula GM, Lago I (2017) Extending the evaluation of the SoySim model to soybean cultivars with high maturation groups. Field Crops Research 201:162-174. DOI: https://doi.org/10.1016/j.fcr.2016.11.006 
CONAB - Companhia Nacional de Abastecimento (2019) Acompanhamento de safra brasileira: grãos, maio/2019. CONAB, 20p.

Doorenbos J, Kassam AH (1979) Yield response to water; irrigation and drainage. Rome, FAO, 193p.

Gimenez L, Paredes P, Pereira LS (2017) Water use and yield of soybean under various irrigation regimes and severe water stress. Application of AquaCrop and SIMDualKc models. Water 9:393. DOI:

https://dx.doi.org/10.3390/w9060393

Graham SL, Kochendorfer J, McMillan AMS, Duncan MJ, Srinivasan MS, Hertzog G (2016) Effects of agricultural management on measurements, prediction, and partitioning of evapotranspiration in irrigated grasslands. Agricultural Water Management 177:340-347. DOI: https://doi.org/10.1016/j.agwat.2016.08.015

Klocke NL, Currie RS, Tomsicek DJ, Koehn JW (2012) Sorghum yield response to deficit irrigation. Transactions of the ASABE 55:947-955. DOI:

https://doi.org/10.13031/2013.41526

Kool D, Agam N, Lazarovitch N, Heitman JL, Sauer TJ, Ben-Gal A (2014) A review of approaches for evapotranspiration partitioning. Agricultural and Forest Meteorology 184:56-70. DOI:

https://doi.org/10.1016/j.agrformet.2013.09.003

Kottek M, Grieser J, Beck C, Rudolf B, Rubel F (2006) World map of the Koppen-Geiger climate classification updated, Meteorologische Zeitschrift 15(3):259-263. DOI: https://doi.org/10.1127/0941-2948/2006/0130

Liu Y, Pereira LS, Fernando RM (2006) Fluxes through the bottom boundary of the root zone in silty soils: Parametric approaches to estimate groundwater contribution and percolation. Agricultural Water Management 84:27-40. DOI: http://doi: 10.1016/j.agwat.2006.01.018

Ma Y, Song X (2019) Applying stable isotopes to determine seasonal variability in evapotranspiration partitioning of winter wheat for optimizing agricultural management practices. Science of the Total Environment 654:633-642. DOI:

https://doi.org/10.1016/j.scitotenv.2018.11.176

Merriam JL, Keller J (1978) Farm irrigation system evaluation: A guide for management. Logan, Utah St. Univ., 271p.

Moreira V, Roberti D, Minella JP, Gonçalves LGG, Candido LA, Fiorin FE, Moraes OLL, Timm AU, Carlesso R, Degrazia GA (2015) Seasonality of soil water exchange in the soybean growing season in southern Brazil. Scientia Agricola 72(2):103-113. DOI:

http://dx.doi.org/10.1590/0103-9016-2014-0056

Odhiambo LO, Irmak S (2012) Evaluation of the impact of surface cover on single and dual crop coefficient for estimating soybean actual evapotranspiration. Agricultural Water Management 104:221-234. DOI: https://doi.org/10.1016/j.agwat.2011.12.021
Paredes P, Rodrigues GJ, Petry M, Severo PO, Carlesso R, Pereira LS (2018) Evapotranspiration partition and crop coefficients of Tifton 85 Bermudagrass as affected by the frequency of cuttings. Application of the FAO56 Dual Kc Model. Water 558:2-20. DOI: https://doi.org/10.558. $10.3390 /$ w 10050558

Paredes P, Wei Z, Liu Y, Xu D, Xin Y, Zhang B, Pereira, LS (2015) Performance and assessment of the FAO AquaCrop model for soil water, soil evaporation, biomass and yield of soybeans in North China Plain. Agricultural Water Management 152:57-71.

Payero JO, Irmak S (2013) Daily energy fluxes, evapotranspiration and crop coefficient of soybean. Agricultural Water Management 129:31-43, 2013. DOI: http://dx.doi.org/10.1016/j.agwat.2013.06.018

Payero JO, Tarkalson DD, Irmak S, Davison D, Petersen JL (2009) Effect of timing of a deficit-irrigation allocation on corn evapotranspiration, yield, water use efficiency and dry mass. Agricultural Water Management 96:1387-1397. DOI: https://doi.org/10.1016/j.agwat.2009.03.022

Pereira LS, Paredes P (2018) Modelling water use on farms. In: Oweis T. Water management for sustainable agriculture. Burleigh Dodds Science, p1-28. DOI: http://dx.doi.org/10.19103/AS.2017.0037.15

Pereira LS, Paredes P, Rodrigues GC, Neves M (2015) Modeling malt barley water use and evapotranspiration partitioning in two contrasting rainfall years, Assessing AquaCrop and SIMDualKc models. Agricultural Water Management 159:239-254. DOI:

https://doi.org/10.1016/j.agwat.2015.06.006

Qiu R, Du T, Kang S, Chen R, Wu L (2015) Assessing the SIMDualKc model for estimating evapotranspiration of hot pepper grown in a solar greenhouse in Northwest China, Agricultural Systems 138:1-9. DOI: https://doi.org/10.1016/j.agsy.2015.05.001

Ran H, Kang S, Li F, Tong L, Ding R, Du T, Li S, Zhang $X$ (2017) Performance of AquaCrop and SIMDualKc models in evapotranspiration partitioning on full and deficit irrigated maize for seed production under plastic film-mulch in an arid region of China. Agricultural Systems 151:20-32. DOI: https://doi.org/10.1016/j.agsy.2016.11.001

Richter GL, Zanon AJ, Streck NA, Guedes JVC, Kräulich B, Rocha TSM, Wink JEM, Cera JC (2014) Estimating leaf area of modern soybean cultivars by a non-destructive method. Bragantia 73:416-425. DOI: https://doi:10.1590/1678-4499.0179

Rodrigues GC, Paredes P, Gonçalves JM, Alves I, Pereira LS (2013) Comparing sprinkler and drip irrigation systems for full and deficit irrigated maize using multicriteria. Agricultural Water Management 126:85-96. DOI: https://doi.org/10.1016/j.agwat.2013.05.005 
Rosa RD, Paredes P, Rodrigues GC, Alvez I, Fernando RM, Pereira LS (2012) Implementing the dual crop coefficient approach in interactive software. 1. Background and computational strategy. Agricultural Water Management 103:8-24. DOI:

https://doi.org/10.1016/j.agwat.2011.10.013

Soil Survey Staff (2014) Keys to soil taxonomy. Washington, Natural Resources Conservation Service, $12^{\text {th }}$ ed.

Stewart JI, Hagan RM, Pruitt WO, Danielson RE, Franklin WT, Hanks RJ, Riley JP, Jackson EB (1977) Optimizing crop production through control of water and salinity levels in the soil. Logan, Utah, Water Research Laboratory, 191p.
Streck EV, Kämpf N, Dalmolin RSD, Klamt E, Nascimento PC, Schneider P, Giasson E, Pinto LFS (2008) Solos do Rio Grande do Sul. 2. ed. Porto Alegre, EMATER/RS, $38 \mathrm{p}$.

UNESCO - Organização das Nações Unidas Para a Educação, a Ciência e a Cultura (2018) Relatório mundial das Nações Unidas sobre desenvolvimento dos recursos hídricos, UNESCO, 12p.

Wei Z, Paredes P, Liu Y, Chi WW, Pereira LS (2015) Modelling transpiration, soil evaporation and yield prediction of soybean in North China Plain. Agricultural Water Management 147:43-53. DOI: https://doi.org/10.1016/j.agwat.2014.05.004 